\title{
Arthrobacter flavus sp. nov., a psychrophilic bacterium isolated from a pond in McMurdo Dry Valley, Antarctica
}

\author{
G. S. N. Reddy, ${ }^{1}$ R. K. Aggarwal, ${ }^{1}$ G. I. Matsumoto ${ }^{2}$ and S. Shivaji ${ }^{1}$ \\ Author for correspondence: S. Shivaji. Tel: +91 40 7172241. Fax: +91 407171195. \\ e-mail: shivas@ccmb.ap.nic.in
}

\footnotetext{
${ }^{1}$ Centre for Cellular and Molecular Biology, Uppal Road, Hyderabad 500 007, India

2 Department of Environmental Information Science, Otsuma Women's University, Tamashi, Tokyo 206, Japan
}

\begin{abstract}
CMS 19Y', a psychrophilic bacterium, was isolated from a cyanobacterial mat sample from a pond in Antarctica and was characterized taxonomically. The bacterium was aerobic, Gram-positive, non-spore-forming, non-motile, exhibited a rod-coccus growth cycle and produced a yellow pigment that was insoluble in water but soluble in methanol. No growth factors were required and it was able to grow between 5 and $30{ }^{\circ} \mathrm{C}$, between pH 6 and pH 9 and tolerated up to $11.5 \% \mathrm{NaCl}$. The cell wall peptidoglycan was Lys-Thr-Ala3 (the A3 $\alpha$ variant) and the major menaquinone was $M K-9\left(H_{2}\right)$. The $G+C$ content of the DNA was $64 \pm 2$ mol\%. The 165 rDNA analysis indicated that CMS $19 Y^{\top}$ is closely related to group I Arthrobacter species and showed highest sequence similarity (97.91\%) with Arthrobacter agilis. Furthermore, DNA-DNA hybridization studies also indicated $77 \%$ homology between CMS $19 Y^{\top}$ and A. agilis. It differed from $A$. agilis, however, in that it was psychrophilic, nonmotile, yellow in colour, exhibited a rod-coccus growth cycle, had a higher degree of tolerance to $\mathrm{NaCl}$ and was oxidase- and urease-negative and lipasepositive. In addition, it had a distinct fatty acid composition compared to that of $A$. agilis: the predominant fatty acids were $C_{15: 0}$, anteiso- $C_{15: 0}, C_{16: 0}$, iso- $C_{16: 0 \text {, }}$ $C_{17: 0}$, anteiso- $C_{17: 0}$ and $C_{18: 0}$. It is proposed, therefore, that CMS $19 Y^{\top}$ should be placed in the genus Arthrobacter as a new species, i.e. Arthrobacter flavus sp. nov. The type strain of $A$. flavus is CMS $19 Y^{\top}(=$ MTCC 3476 $)$.
\end{abstract}

Keywords: Arthrobacter, psychrophile, Antarctica, halotolerant, yellow pigment

\section{INTRODUCTION}

Members of the genus Arthrobacter constitute a predominant group of micro-organisms in soils from various parts of the world. In addition to mesophilic arthrobacters (Schleifer \& Kandler, 1972; Keddie \& Jones, 1981; Keddie et al., 1986), psychrophilic arthrobacters have been reported from samples of subterranean cave silts (Gounot, 1967), glacier silts (Moiroud \& Gounot, 1969) and the soils of Antarctica (Johnson et al., 1981; Johnson \& Bellinoff, 1981; Madden et al., 1979; Siebert \& Hirsch, 1988; Shivaji et al., 1989a). The psychrophilic isolates of Arthrobacter from Antarctica were identified on the basis of numerous phenotypic genus-specific charac-

Abbreviations: DAP, diaminopimelic acid; NJ, neighbourjoining; UPGMA, unweighted pair group method with averages.

The EMBL accession number for the $16 \mathrm{~S}$ rDNA sequence of CMS $19 \mathrm{Y}^{\top}$ is AJ242532. teristics (Keddie et al., 1986) such as morphology, physiological properties, cell wall composition, $\mathrm{G}+\mathrm{C}$ content of the DNA $(\mathrm{mol} \%)$, menaquinone type, nutritional requirements, antibiotic sensitivity and biochemical test results (Johnson et al., 1981; Johnson \& Bellinoff, 1981; Shivaji et al., 1989a). Despite these similarities, the above Antarctic strains differed from the mesophilic species of Arthrobacter in that they were all psychrophilic, contained glucose as the cell wall sugar and did not hydrolyse starch. Pigmented Arthrobacter strains containing LL-diaminopimelic acid (LL-DAP) in the cell wall have also been reported from Antarctic soils (Siebert \& Hirsch, 1988). Many of these Arthrobacter strains from Antarctica are unique in that they are psychrophilic and possess phenotypic traits by which they differ from the mesophilic Arthrobacter strains; thus they cannot be affiliated to any of the known species. These isolates were tentatively assigned to a group in the genus Arthrobacter known as the Arthrobacter simplex/tumescens group (Keddie 
\& Jones, 1981; Johnson et al., 1981; Johnson \& Bellinoff, 1981; Siebert \& Hirsch, 1988). Arthrobacter simplex and Arthrobacter tumescens have now been reclassified as Pimelobacter simplex and Pimelobacter tumescens (Suzuki \& Komagata, 1983a, b).

All of the species of the genus Arthrobacter are Grampositive, catalase-positive, aerobic and asporogenous bacilli with a coryneform morphology (Schleifer \& Kandler, 1972) and have been separated into two groups on the basis of their peptidoglycan, which contains lysine as the diamino acid. Group I species of Arthrobacter contain the A $3 \alpha$ peptidoglycan variant in which cross-linkage of murein is brought about by interpeptide bridges involving monocarboxylic Lamino acids or glycine or both, as observed in most species of Arthrobacter including Arthrobacter globiformis, the type strain of the genus (Stackebrandt et al., 1983). The group II species of Arthrobacter possess the A $4 \alpha$ peptidoglycan variant in which the peptidoglycan type is L-Lys-Ala-Glu, as in Arthrobacter nicotianae, Arthrobacter uratoxydans, Arthrobacter protophormiae (Schleifer \& Kandler, 1972; Stackebrandt et al., 1983), or L-Lys-L-Glu, as in Arthrobacter sulfureus (Stackebrandt et al., 1995; Funke et al., 1996). Recently, Arthrobacter rhombi, a new species (isolated from Greenland halibut) with A $4 \alpha$ peptidoglycan, was also included in Arthrobacter group II (Osorio et al., 1999). Phylogenetic studies indicate that certain Micrococcus species such as Micrococcus agilis, Micrococcus lylae and Micrococcus luteus are intermixed with the species of Arthrobacter (Stackebrandt et al., 1995) and detailed phylogenetic analysis along with phenotypic similarities have resulted in the reclassification of $M$. agilis as Arthrobacter agilis (Koch et al., 1995). The genus also includes a number of other species for which the chemotaxonomic data are lacking, e.g. Arthrobacter mysorens, Arthrobacter picolinophilus, Arthrobacter radiotolerans and Arthrobacter siderocapsulatus (Keddie et al., 1986). Detailed studies have now reclassified A. picolinophilus as Rhodococcus erythropolis (Koch et al., 1995) and A. radiotolerans as Rubrobacter radiotolerans (Suzuki et al., 1989). It has also been shown that A. mysorens is distinct from the Arthrobacter species recognized up to 1983 (Stackebrandt et al., 1983). Furthermore, many other species that were included in the genus Arthrobacter (e.g. Arthrobacter duodecadis, Arthrobacter viscosus, Arthrobacter variabilis, A. simplex and A. tumescens) have now been excluded since they contain meso-DAP or LL-DAP in the peptidoglycan (Stackebrandt et al., 1983).

In the present study, CMS $19 \mathrm{Y}^{\mathrm{T}}$, a psychrophilic bacterium isolated from a cyanobacterial mat growing luxuriously in a pond in McMurdo Dry Valley, Antarctica, has been identified as belonging to the genus Arthrobacter. It possessed most of the phenotypic characteristics of Arthrobacter. Furthermore, the phylogenetic analysis based on the 16S rRNA gene of CMS $19 \mathrm{Y}^{\mathrm{T}}$ also indicated that it is closely related to group I Arthrobacter spp., which contain A $3 \alpha$-variant peptidoglycan. It differed, however, from all of the reported mesophilic and psychrophilic species with respect to many characteristics and was therefore designated as a new species, for which we propose the name Arthrobacter flavus sp. nov.

\section{METHODS}

Source of the organism, media and growth conditions. Cyanobacterial mat samples were collected during the austral summer from the shores of an unnamed pond, designated E4 $\left(77^{\circ} 31^{\prime} 7^{\prime \prime} \mathrm{S}, 160^{\circ} 45^{\prime} 4^{\prime \prime} \mathrm{E}\right)$, from the labyrinth of the Wright Valley, a constituent valley of McMurdo Dry Valley, Antarctica (Matsumoto, 1993; Matsumoto et al., 1993). The sample was initially analysed microscopically $(\times 1000)$ and found to contain Phormidium laminosum as the most abundant cyanobacterium and also contained some green algae (Matsumoto et al., 1993).

For the detection of bacteria, a piece of the above cyanobacterial mat sample (approx. $200 \mathrm{mg}$ ) was suspended in a tube containing $1 \mathrm{ml}$ sterile saline $(150 \mathrm{mM} \mathrm{NaCl})$, teased with a glass rod and vortexed for approximately 2-5 min to obtain a suspension. An aliquot of the suspension $(100 \mu \mathrm{l})$ was plated on Antarctic Bacterial Medium (ABM) plates containing $0.5 \%(\mathrm{w} / \mathrm{v})$ peptone, $0 \cdot 1 \%(\mathrm{w} / \mathrm{v})$ yeast extract and $1.5 \%(\mathrm{w} / \mathrm{v})$ agar $(\mathrm{pH} 6.9)$ and incubated at $10{ }^{\circ} \mathrm{C}$ (Shivaji et al., 1988, 1989a, b, 1991, 1992). The appearance of colonies was monitored on a regular basis and pure cultures of the bacteria were established. One of the pure cultures thus established was yellow in colour and was designated CMS $19 \mathrm{Y}^{\mathrm{T}}$. The optimal temperature, $\mathrm{pH}$ and salt concentration for the growth of CMS $19 \mathrm{Y}^{\mathrm{T}}$ were determined by using ABM plates.

Morphology and motility tests. Cultures of CMS $19 \mathrm{Y}^{\mathrm{T}}$ in the lag-, log- and stationary phases of growth were observed under a phase-contrast microscope $(1000 \times)$ to ascertain their shape and motility. Motility was also determined by the hanging drop method and staining of the flagellum was done by the method of silver impregnation (Blenden \& Goldberg, 1965) using Pseudomonas aeruginosa as a positive control.

Biochemical characteristics. All of the tests were performed by growing the culture at $20^{\circ} \mathrm{C}$ in the appropriate medium. The activities of catalase, oxidase, phosphatase, gelatinase, urease, arginine dihydrolase and $\beta$-galactosidase were determined according to standard methods (Holding \& Collee, 1971). The production of indole, the utilization of citrate, the reduction of nitrate to nitrite and the hydrolysis of starch, aesculin and Tween 80 were measured according to the procedures described elsewhere (Stanier et al., 1966; Holding \& Collee, 1971; Stolp \& Gadkari, 1981). The utilization of six different sugars, leading to the formation of acid with or without gas production, was monitored according to Hugh \& Leifson (1953).

Fifty-four different carbon compounds were used to check the ability of the culture to utilize a carbon compound provided as the sole carbon source, using minimal medium without glucose but containing $0 \cdot 2 \%(\mathrm{w} / \mathrm{v})$ of the carbon source (Shivaji et al., 1988, 1989a, b, 1992). The sensitivity of the culture to 24 different antibiotics was determined using antibiotic discs (HiMedia).

Preparation of DNA and $\mathbf{G}+\mathbf{C}$ content. DNA was isolated according to the procedure of Marmur (1961) and the $\mathrm{G}+\mathrm{C}$ content $(\mathrm{mol} \%)$ was determined from the melting point $\left(T_{\mathrm{m}}\right)$ curves obtained using a Hitachi Spectrophotometer as 
described earlier (Shivaji et al., 1989a, b, 1991, 1992). The equation of Schildkraut \& Leifson (1965) was used to calculate the $\mathrm{G}+\mathrm{C}$ content $(\mathrm{mol} \%$ ) of the DNA.

DNA-DNA hybridization. DNA-DNA hybridization between CMS $19 \mathrm{Y}^{\mathrm{T}}$ and $A$. agilis DNA was performed by using the membrane filter method (Tourova \& Antonov, 1987) according to the protocol described earlier (Shivaji et $a l ., 1992$ ). DNA was denatured by boiling in $0 \cdot 2 \mathrm{M} \mathrm{NaOH}$ for $5 \mathrm{~min}$ and then quickly chilling on ice and neutralizing with $\mathrm{HCl}$. Denatured DNA was dotted on to nitrocellulose and immobilized by baking at $80{ }^{\circ} \mathrm{C}$ for $2 \mathrm{~h}$. The filters with the fixed DNA were prehybridized in a buffer containing $4 \times$ $\mathrm{SSC}(1 \times \mathrm{SSC}$ is $0.15 \mathrm{M} \mathrm{NaCl}$ plus $0.015 \mathrm{M}$ sodium citrate $)$, $5 \times$ Denhardt's medium (Denhardt, 1966), calf-thymus DNA $\left(100 \mu \mathrm{g} \mathrm{ml}^{-1}\right)$ and $1 \% \operatorname{SDS}$ for $2 \mathrm{~h}$ at $60^{\circ} \mathrm{C}$ and then hybridized in the same buffer under similar conditions but in the presence of labelled DNA. DNA was labelled by nick translation (Rigby et al., 1977).

Analysis of cellular fatty acids. Cellular fatty acid methyl esters were obtained using the method described by Stead et al. (1992) and were separated by GC on an Hewlett-Packard HP-5-type silicon capillary column $(25 \mathrm{~m} \times 0.25 \mathrm{~mm})$. The fatty acids were identified by comparison with fatty acid standards run under similar gas chromatographic conditions and also by MS (VG AUTOSPEC) (Shivaji et al., 1992).

Analysis of isoprenoid quinones. Menaquinones were extracted as described by Collins et al. (1977) and were separated by TLC using petroleum ether and diethyl ether $(85: 15, \mathrm{v} / \mathrm{v})$. The menaquinone band corresponding to an $R_{\mathrm{F}}$ value of 0.7 was separated, eluted with chloroform and further resolved into individual menaquinones by TLC, using silica-gel plates impregnated with silver nitrate with $15 \%$ methyl ethyl ketone in hexane as the solvent system (Dumphy et al., 1971). The identities of the individual menaquinones were also confirmed by MS.

Analysis of polar lipids. Lyophilized cell pellets washed free of medium were used for the extraction of polar lipids by the method of Minnikin et al. (1975) and were identified by TLC.

Peptidoglycan analysis. Peptidoglycan was prepared according to the method described by Rosenthal \& Dziarski (1994). The peptidoglycan thus obtained was hydrolysed with $4 \mathrm{M}$ $\mathrm{HCl}$ at $120^{\circ} \mathrm{C}$ for $60 \mathrm{~min}$. The hydrolysate was vacuumdried and the amino acids were extracted into acetate buffer (pH 4.6) and subjected to amino acid analysis on an automated amino acid analyser (model 80-2086-6314; Pharmacia). The composition of the peptidoglycan was determined according to the method of Schleifer \& Kandler (1972)

Cell wall sugars. Cell wall sugars were prepared and analysed according to the method described by Komagata \& Suzuki (1987).

Bacterial pigment analysis. Lyophilized cells of CMS $19 \mathrm{Y}^{\mathrm{T}}$ were suspended, extracted with methanol, centrifuged and the clear yellow supernatant recovered; the absorption spectrum was recorded in a Hitachi 330 spectrophotometer (Jagannadham et al., 1991; Shivaji et al., 1992; Chauhan \& Shivaji, 1994).

PCR amplification of the 16S rRNA gene. The small-subunit rRNA gene was amplified using the two primers $16 \mathrm{~S} 1$ ( $^{\prime}$ GAGTTTGATCCTGGCTCA-3') and 16S2 (5'-ACGGCTACCTTGTTACGACTT-3'), which are complementary to the conserved regions at the $5^{\prime}$ - and $3^{\prime}$ ends of the $16 \mathrm{~S}$
rRNA gene corresponding to positions 9-27 and 1477-1498 of the Escherichia coli 16S rRNA gene (Lane, 1991). The bacterial DNA $(0.5 \mu \mathrm{g})$ was amplified by the PCR in a total volume of $50 \mu \mathrm{l}$ containing $0.5 \mathrm{U}$ Taq DNA polymerase, $10 \mathrm{mM}$ TAPS, pH 8.8, $3 \mathrm{mM} \mathrm{MgCl}_{2}, 50 \mathrm{mM} \mathrm{KCl}, 0.01 \%$ gelatin, $10 \mathrm{pmol}$ of each of the two primers and $200 \mu \mathrm{M}$ each of dATP, dCTP, dGTP and TTP. The amplification of DNA was carried out in a hot-air rapid thermocycler (model no. 1833; Idaho Technologies) programmed for 40 cycles of denaturation at $94{ }^{\circ} \mathrm{C}$ for $10 \mathrm{~s}$, annealing at $48^{\circ} \mathrm{C}$ for $20 \mathrm{~s}$ and extension at $72^{\circ} \mathrm{C}$ for $30 \mathrm{~s}$. A final extension of $5 \mathrm{~min}$ was carried out at $72{ }^{\circ} \mathrm{C}$. In all of the amplification reactions, water was used in place of DNA for negative controls. The amplified DNA fragment $(1.5 \mathrm{~kb})$ was separated on $1 \%$ agarose gel, eluted from the gel and purified using the Clean Genei Kit (Bangalore Genei). The purified PCR product was used directly for DNA sequencing.

16S rRNA gene sequencing. The purified $1.5 \mathrm{~kb}$ DNA product was sequenced using the primers $16 \mathrm{~S} 1$ and $16 \mathrm{~S} 2$ and, in addition, a set of five forward primers [pB (TAACACATGCAAGTCGAACG), 50-70; pC (CTACGGGAGGCAGCAGTGGG), 341-361; pD (CAGCAGCCGCGGTAATAC), 518-536; pE (AAACTCAAAGGAATTGACGG), 908-928; and pF (CATGGCTGTCGTCAGCTCGT), 1053-1073] and one reverse primer $\left[\mathrm{pC}^{\circ}\right.$, (CCCACTGCTGCCTCCCGTAG), 301-341]. The nucleotide positions of the synthetic oligomers (as indicated in parentheses) are related to the $16 \mathrm{~S}$ rDNA of $E$. coli (Woese et al., 1983).

Sequencing of the purified PCR product $(\sim 200 \mathrm{ng} /$ reaction) was carried out using $5 \mathrm{pmol}$ of a given sequencing primer and $8 \mu \mathrm{l}$ ready-reaction mix from either the Big Dye Terminator sequencing kit (Perkin Elmer) or the Thermo Sequenase Dye Terminator cycle sequencing kit (Amersham) in a total volume of $20 \mu \mathrm{l}$. Cycle sequencing was carried out in a GeneAmp PCR machine (9600; Perkin Elmer). The thermal sequence consisted of 30 cycles as follows: $96^{\circ} \mathrm{C}$ for $10 \mathrm{~s}, 50^{\circ} \mathrm{C}$ for $5 \mathrm{~s}$ and $60^{\circ} \mathrm{C}$ for $4 \mathrm{~min}$. After the PCR, the products were precipitated using $2 \mu \mathrm{l}$ sodium acetate ( $3 \mathrm{M}, \mathrm{pH} 4.6)$ and $125 \mu$ lethanol and stored on ice for $10 \mathrm{~min}$. The pellet was recovered by centrifugation at 15000 r.p.m. for $20 \mathrm{~min}$ at $4{ }^{\circ} \mathrm{C}$, washed with $70 \%$ ethanol, dried under vacuum and dissolved in $4 \mu$ l loading buffer [formamide:25 mM EDTA (4:1)]. The samples were denatured for $2 \mathrm{~min}$ at $90{ }^{\circ} \mathrm{C}$ before being loaded on to the sequencing gel $(6 \%$ bis-acrylamide gel). Two-microlitre aliquots from each sample were loaded per gel lane and the gel was run for $10 \mathrm{~h}$ on a DNA sequencer (ABI Prism model 377 version 2.1.1).

Phylogenetic analysis. The $16 \mathrm{~S}$ rDNA sequence of CMS $19 \mathrm{Y}^{\mathrm{T}}$ was aligned with 31 reference sequences (Fig. 1) from the EMBL database, using the multiple sequence alignment program CLUSTAL V (Higgins et al., 1992). The aligned sequences were then manually checked for gaps. The pairwise evolutionary distances for the above aligned sequences were computed using the DNADIST program with the Kimura two-parameter model (Kimura, 1980). To obtain the confidence values for the rDNA sequence-based genetic affiliations, the original sequence data set was resampled 100 times using SEQBOOT and subjected to bootstrap analysis. The multiple distance matrices thus obtained were used to construct phylogenetic trees showing the relationships between CMS $19 \mathrm{Y}^{\mathrm{T}}$ and other reference micro-organisms, using various distance matrix-based clustering algorithms [FITCH, the unweighted pair group method with averages (UPGMA), KITCH and the neighbour-joining (NJ) method] 


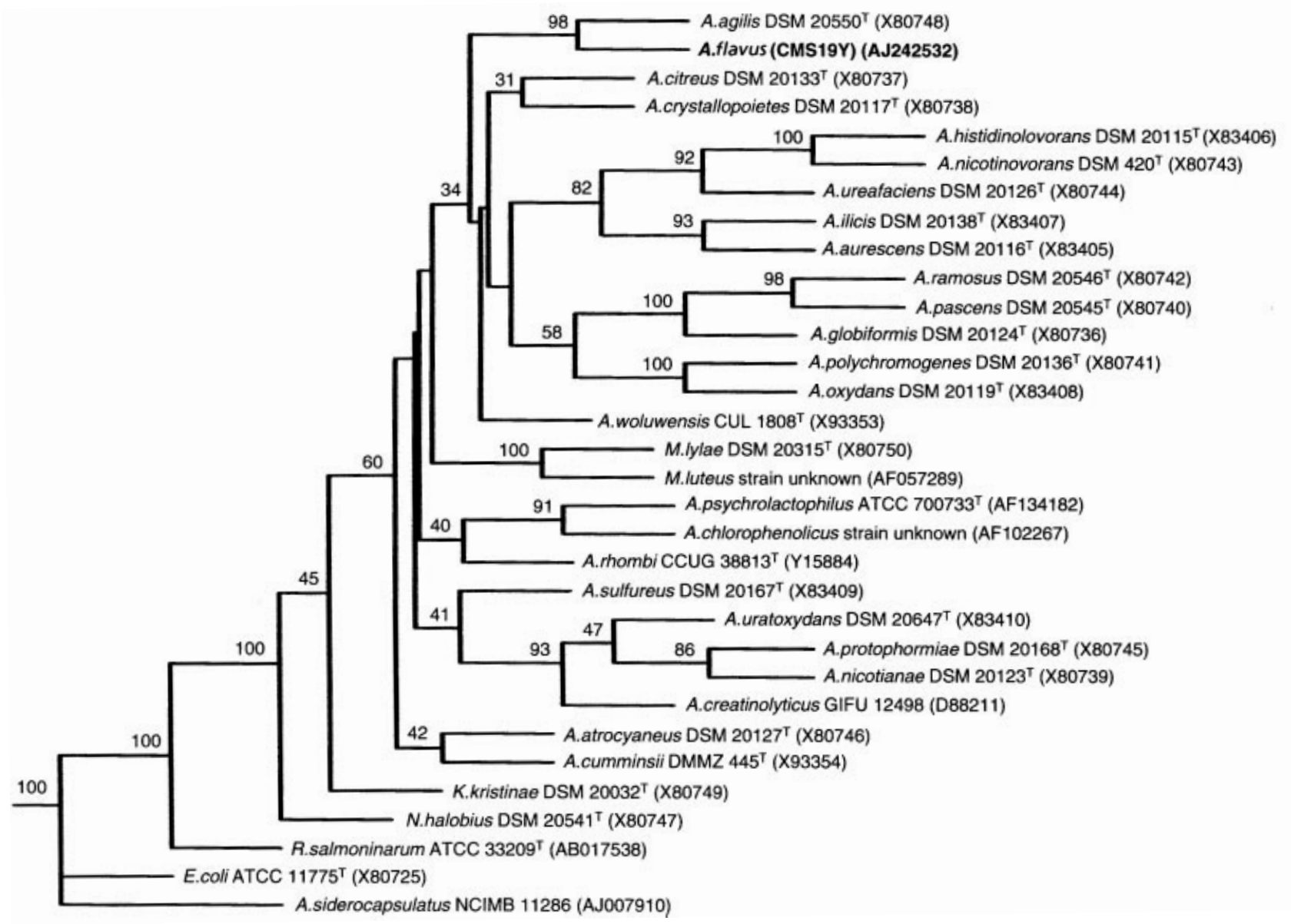

Fig. 1. UPGMA phenogram showing the phylogenetic relationship between $\mathrm{CMS}^{19 Y^{\top}}$, Arthrobacter species and other related reference micro-organisms, based on the 16S rDNA sequence analysis. The evolutionary distances were computed using the Kimura two-parameter model in DNADIST. The bootstrap analysis was done to check the reliability of the tree. The bootstrap values (\%) are given at the nodes to which they apply; values below $30 \%$ are omitted. The branch lengths indicated in the phenogram are not to scale.

included in the Phylogeny Inference Package (Felsenstein, 1993). Parsimony analysis was also performed for the aligned sequence data set, using DNAPARS and DNAML. In all cases, the input order of species added to the topology being constructed was randomized via the jumble option with random seed of 7 and 10 replications. Majority-rule (50\%) consensus trees were constructed for the topologies found by each method by using CONSENSE. All of these analyses were performed using the PHYLIP package, version 3.5C (Felsenstein, 1993).

Reference strains. M. luteus (ATCC 4698), Micrococcus roseus (reclassified as Kocuria rosea) (ATCC 412), $A$. globiformis (ATCC 8010), A. protophormiae (MTCC 693), $P$. aeruginosa (NCTC 675) and Sphingobacterium antarcticus (ATCC 51970) were used as controls in the studies relating to morphology, motility, biochemical tests, identification of fatty acids, etc.

\section{RESULTS AND DISCUSSION}

A colony of CMS $19 \mathrm{Y}^{\mathrm{T}}$ was isolated and purified from a cyanobacterial mat sample from the Wright Valley located in the McMurdo Dry Valley region of
Antarctica. The cyanobacterial mat sample, following suspension in sterile water, plating on ABM and incubation at $10^{\circ} \mathrm{C}$, yielded approximately $1 \times 10^{4}$ colonies per $\mathrm{g}$ mat sample after $15 \mathrm{~d}$. All of the colonies were either white or orange in colour, except CMS $19 \mathrm{Y}^{\mathrm{T}}$ (which was yellow in colour). The yellow colonies of CMS $19 \mathrm{Y}^{\mathrm{T}}$ were $0.5-2 \mathrm{~mm}$ in diameter, round, smooth and convex. Table 1 summarizes some of the phenotypic characteristics of CMS $19 \mathrm{Y}^{\mathrm{T}}$; details relating to pigment production, the UV-visible spectrum of the pigment, optimal growth conditions, the utilization of carbon compounds as sole carbon sources, the ability to oxidize or ferment sugars, sensitivity to antibiotics and other phenotypic characteristics are included below in the description of the species.

The cellular fatty acids were identified as $\mathrm{C}_{14: 0}(1 \cdot 6 \%)$, $\mathrm{C}_{15: 0}(2 \cdot 8 \%)$, anteiso- $\mathrm{C}_{15: 0}(52 \%), \mathrm{C}_{16: 0}(2 \cdot 2 \%)$, iso$\mathrm{C}_{16: 0}(17 \%), \mathrm{C}_{16: 1}(0 \cdot 6 \%), \mathrm{C}_{17: 0}(12 \cdot 8 \%)$, anteiso$\mathrm{C}_{17: 0}(7 \cdot 2 \%)$, iso- $\mathrm{C}_{18: 0}(0 \cdot 21 \%), \mathrm{C}_{18: 0}(2 \cdot 6 \%)$ and $\mathrm{C}_{20}$ $(1 \%)$. Glucose, ribose and galactose were the cell wall 
Table 1. Phenotypic characteristics of $\mathrm{CMS} 19 \mathrm{Y}^{\top}$ and Arthrobacter agilis

+ , Positive; -, negative.

\begin{tabular}{|c|c|c|}
\hline Characteristic & CMS 19Y & A. agilis \\
\hline Colony diameter (mm) & $0 \cdot 5-2 \cdot 0$ & - \\
\hline Colony colour & Yellow & Red \\
\hline Form & Rod-coccus & Coccoid \\
\hline Motility & - & $+1-$ \\
\hline Flagella & - & $1-3$ \\
\hline Spore formation & No & No \\
\hline Gram reaction & Positive & Positive \\
\hline Catalase & + & + \\
\hline Oxidase & - & + \\
\hline Urease & - & - \\
\hline Lipase & + & - \\
\hline Gelatinase & + & + \\
\hline Phosphatase & - & - \\
\hline$\beta$-Galactosidase & + & + \\
\hline Aesculin hydrolysis & + & + \\
\hline Starch hydrolysis & - & + \\
\hline Nitrate to nitrite reduction & - & - \\
\hline Indole test & - & - \\
\hline Methyl red test & - & - \\
\hline Voges-Prosauker test & - & - \\
\hline Levan formation & - & - \\
\hline \multicolumn{3}{|l|}{ Arginine dihydrolase } \\
\hline Aerobic & + & - \\
\hline Anaerobic & - & - \\
\hline Peptidoglycan variant & $\mathrm{A} 3 \alpha$ & $\mathrm{A} 3 \alpha$ \\
\hline Peptidoglycan type & Lys-Thr-Ala3 & Lys-Thr-Ala3 \\
\hline Major menaquinone & MK-9 $\left(\mathrm{H}_{2}\right)$ & MK-9 $\left(\mathrm{H}_{2}\right)$ \\
\hline Cellular fatty acids & $\begin{array}{c}\mathrm{C}_{14: 0}, \mathrm{C}_{15: 0}, \text { anteiso- } \mathrm{C}_{15: 0}, \\
\mathrm{C}_{16: 0}, \text { iso- }_{16: 0}, \mathrm{C}_{16: 1}, \\
\mathrm{C}_{17: 0}, \text { anteiso- } \mathrm{C}_{17: 0}, \text { iso- }_{18: 0} \\
\mathrm{C}_{18: 0}, \mathrm{C}_{20: 0}\end{array}$ & $\begin{array}{l}\text { anteiso- } C_{15: 0}, \\
\quad \text { iso- } C_{15: 0} \\
\text { iso-C }_{16: 1}\end{array}$ \\
\hline Cell wall sugars & Galactose, glucose, ribose & Glucosamine \\
\hline DNA $\mathrm{G}+\mathrm{C}$ content $(\mathrm{mol} \%)$ & $64 \cdot 4 \pm 2 \cdot 44$ & $67-70 \cdot 0$ \\
\hline
\end{tabular}

sugars and the peptidoglycan type was L-Lys-Thr-L$\mathrm{Ala}_{3}$ of the $\mathrm{A} 3 \alpha$ peptidoglycan variant. The major menaquinone was MK- $9\left(\mathrm{H}_{2}\right)$ and the lipids were identified as phosphatidylglycerol, cardiolipin and phosphatidylethanolamine. The $\mathrm{G}+\mathrm{C}$ content $(\mathrm{mol} \%)$ of the DNA of CMS $19 \mathrm{Y}^{\mathrm{T}}$ was $64 \pm 2\left(T_{\mathrm{m}}\right.$ $\left.79 \cdot 5^{\circ} \mathrm{C} \pm 1\right)$.

The characteristics of CMS $19 \mathrm{Y}^{\mathrm{T}}$ (see the description of the species, below) were observed to be consistent with the description of the genus Arthrobacter with respect to various phenotypic characteristics including cell wall composition, menaquinone type and the $\mathrm{G}+\mathrm{C}$ content $(\mathrm{mol} \%)$ of the DNA (Keddie \& Jones, 1981; Keddie et al., 1986). There are several other genera, which, like Arthrobacter, have a rod-coccus growth cycle, e.g. Brevibacterium, Caseobacter, Rhodococcus and Microbacterium (Keddie et al., 1986; Takeuchi \& Hatano, 1998). However, species in these genera have ornithine or DAP as the diamino acid in the cell wall unlike species of Arthrobacter, which have lysine as the diamino acid in the cell wall (Keddie et al., 1986).

CMS 19Y ${ }^{\mathrm{T}}$ differs from all of the reported psychrophilic and mesophilic species of Arthrobacter in a number of phenotypic characteristics. The genus Arthrobacter includes a few species that are unpigmented (A. globiformis, Arthrobacter crystallopoietes, Arthrobacter pascens and Arthrobacter histidinolovorans) but a good majority of them produce a range of pigments, e.g. yellow (Arthrobacter aurescens, Arthrobacter ilicis, Arthrobacter citreus, A. nicotianae, A. protophormiae, Arthrobacter uratoxydans, A. sulfureus and A. mysorens), grey to yellow (Arthrobacter ureafaciens, Arthrobacter oxydans and A. siderocapsulatus), blue to black (Arthrobacter atrocyaneus) and red pigment (A. agilis) (Keddie et al., 1986; Schleifer, 1986; Koch et al., 1995). Thus CMS 19Y ${ }^{\mathrm{T}}$, which produces a yellow pigment, could be any one of the eight above 
Table 2. Some characteristics by which CMS $19 \mathrm{Y}^{\top}$ differs from the yellow-pigmented Arthrobacter spp. with $\mathrm{A} 3 \alpha$-variant peptidoglycan and $\mathrm{MK}-9\left(\mathrm{H}_{2}\right)$ as the major menaquinone

\begin{tabular}{|c|c|c|c|c|}
\hline Characteristic & A. aurescens & A. ilicis & A. citreus & CMS 19Y' \\
\hline Motility & - & + & + & - \\
\hline Peptidoglycan type & Lys-Ala-Thr-Ala & Lys-Ala-Thr-Ala & Lys-Thr-Ala2 & Lys-Thr-Ala3 \\
\hline Cell wall sugars & $\begin{array}{l}\text { Galactose } \\
\text { (mannose) }\end{array}$ & $\begin{array}{c}\text { Galactose, } \\
\text { rhamnose, } \\
\text { mannose }\end{array}$ & Galactose & $\begin{array}{c}\text { Galactose, } \\
\text { glucose, ribose }\end{array}$ \\
\hline Starch hydrolysis & + & - & - & - \\
\hline $\begin{array}{l}\text { DNA G }+\mathrm{C} \text { content } \\
(\mathrm{mol} \%)\end{array}$ & $61 \cdot 5$ & $61 \cdot 5$ & $62 \cdot 9-65 \cdot 1$ & $64 \cdot 4 \pm 2 \cdot 4$ \\
\hline
\end{tabular}

species of Arthrobacter that produce a yellow pigment. However, CMS $19 \mathrm{Y}^{\mathrm{T}}$ differs from the above yellowpigmented species in that it has a peptidoglycan of the Lys-Thr-Ala3 type of the A $3 \alpha$ variant. A. aurescens, $A$. ilicis and $A$. citreus also have $\mathrm{A} 3 \alpha$-variant peptidoglycans but differ from CMS $19 \mathrm{Y}^{\mathrm{T}}$ in that their peptidoglycan type is Lys-Ala-Thr-Ala, as in $A$. aurescens and A. ilicis, and Lys-Thr-Ala2, as in A. citreus (Keddie et al., 1986). The remaining five yellow Arthrobacter species have A $4 \alpha$-variant peptidoglycan. Table 2 shows the characteristics by which CMS $19 \mathrm{Y}^{\mathrm{T}}$ differs from the yellow-pigmented Arthrobacter spp. having $\mathrm{A} 3 \alpha$-variant peptidoglycan and MK-9 $\left(\mathrm{H}_{2}\right)$ as the major menaquinone. CMS $19 \mathrm{Y}^{\mathrm{T}}$ also differs from $A$. duodecadis, $A$. variabilis and $A$. viscosus, which have meso-DAP in the peptidoglycan (Keddie et al., 1986), and have thus been excluded from the genus Arthrobacter.

In the mid-1990s, M. agilis was reclassified as A. agilis comb. nov. (Koch et al., 1995). CMS 19Y $\mathrm{Y}^{\mathrm{T}}$ was observed to be similar to A. agilis with respect to many phenotypic characteristics, both have A $3 \alpha$-variant peptidoglycan and the peptidoglycan in both was LysAla-Thr3 (Table 1). DNA-DNA hybridization studies indicated $77 \%$ homology between CMS $19 \mathrm{Y}^{\mathrm{T}}$ and $A$. agilis. Furthermore, the major menaquinone in both was MK-9 $\left(\mathrm{H}_{2}\right)$. Nonetheless, CMS $19 \mathrm{Y}^{\mathrm{T}}$ and $A$. agilis exhibit a number of distinct differences. The reported isolate (CMS $\left.19 \mathrm{Y}^{\mathrm{T}}\right)$ is, unlike $A$. agilis, psychrophilic (it grows at $5-30^{\circ} \mathrm{C}$ ), halotolerant (it is able to grow in the presence of $11.5 \% \mathrm{NaCl}$ ), produces a yellow pigment, is non-motile, has a different fatty acid composition and has galactose, glucose and ribose as the cell wall sugars (Table 1).

In the present study, an attempt was also made to establish the identity and phylogenetic position of CMS $19 \mathrm{Y}^{\mathrm{T}}$ on the basis of its $16 \mathrm{~S}$ rDNA sequence. Accordingly, the 16S rDNA sequence of CMS 19Y ${ }^{\mathrm{T}}$, consisting of 1446 nucleotide base pairs, was compared with 31 corresponding sequences of closely related Arthrobacter species and other reference microorganisms retrieved from the EMBL database. The topology of the consensus phylogenetic trees shown in Fig. 1 is broadly in agreement with those reported recently by Koch et al. (1995) and Hou et al. (1998). The genetic affiliations seen between different species were generally consistent across the different 'distance as well as parsinomy'-based clustering methods, viz. FITCH, KITSCH, UPGMA, NJ, DNAPARS and DNAML. Moreover, it was seen that while most of the Arthrobacter species were grouped into a few highly stable coherent clades (having high bootstrap values of $>50 \%$ ), the inter-clade resolution was not very robust (Fig. 1), an observation also made by Hou et al. (1998). Interestingly, in most of these phylogenetic methods, the group I and group II species of Arthrobacter were clearly separated from each other, supporting the observations made with phenotypic data.

The 16S rDNA-based phylogenetic analysis clearly established CMS $19 \mathrm{Y}^{\mathrm{T}}$ as a member of the genus Arthrobacter (Fig. 1) and, more specifically, as a member of the group I Arthrobacter species, which include the type strain A. globiformis and all other species defined on the basis of the A $3 \alpha$ peptidoglycan variant (Keddie et al., 1986). Within the group I Arthrobacter species, those containing the peptidoglycan Lys-Ser-Thr-Ala (A. oxydans and Arthrobacter polychromogenes) and those with Lys-Ala-Thr-Ala $(A$. aurescens, A. ilicis, Arthrobacter ureafaciens, A. histidinolovorans and Arthrobacter nicotinovorans) appeared in two robust clades that were (relatively) closer to A. pascens, Arthrobacter ramosus and A. globiformis, which formed another robust clade according to most of the clustering methods (Fig. 1). Within group II Arthrobacter species (A. nicotianae, A. protophormiae, Arthrobacter uratoxydans, Arthrobacter creatinolyticus, A. sulfureus, A. rhombi, Arthrobacter psychrolactophilus and Arthrobacter chlorophenolicus) characterized as having the peptidoglycan variant $\mathrm{A} 4 \alpha$, the first three and the last three were more closely related to each other, forming coherent clusters (Fig. 1). Overall, group II Arthrobacter species appeared to be closer to M. lylae and M. luteus than to group I species. In comparison, the genetic affiliations of the remaining known species of Arthrobacter, i.e. A. atrocyaneus, Arthrobacter woluwensis, Arthrobacter cumminsii, A. citreus, A. crystallopoietes and A. siderocapsulatus were well resolved, as none of these species exhibit close 
affinity for any of the above species in particular. Against this background, it was most interesting to note that the new strain (CMS 19Y ${ }^{\mathrm{T}}$ ) always formed a robust cluster with $A$. agilis in both phenetic and parsimony-based phylogenetic analysis, thus strongly defining its genetic affiliation as a member of the group I Arthrobacter spp. (the minimum evolutionary distance from $A$. agilis, according to the Kimura twoparameter model, being $2 \cdot 09 \%$ ).

Thus, the phylogenetic database of $16 \mathrm{~S}$ rDNA sequences strongly suggests that CMS $19 \mathrm{Y}^{\mathrm{T}}$ is an Arthrobacter species (there being high levels of genetic similarity in the range $97 \cdot 91-94 \cdot 25 \%$ ). The observed evolutionary distance of $2.09 \%$ between CMS $19 \mathrm{Y}^{\mathrm{T}}$ and its nearest Arthrobacter species (A. agilis) is significantly more than that seen between many of the other previously described known species of Arthrobacter. For instance, the distances between $A$. pascens and A. globiformis, A. histidinolovorans and A. nicotinovorans, $A$. oxydans and $A$. polychromogenes and $A$. ramosus and $A$. pascens were $0.34,0 \cdot 27,0.07$ and $0 \%$ respectively. These observations suggest that CMS $19 \mathrm{Y}^{\mathrm{T}}$, which is phylogenetically most close to A. agilis, is differentiated enough not to be a strain/isolate or subspecies of the latter or of any other known species of the genus Arthrobacter and is thus defined as a new species. Recently, Stackebrandt \& Goebel (1994) emphasized that DNA-DNA hybridization remains the optimal method for measuring degrees of relatedness and observed that when $16 \mathrm{~S}$ rRNA sequence homology is below $97.5 \%$ it is unlikely that the two organisms have more than $60 \%$ DNA similarity. In the present study, it was observed that the sequence homology between CMS $19 \mathrm{Y}^{\mathrm{T}}$ and $A$. agilis was $97.91 \%$ and that the DNA-DNA similarity was $77 \%$, thus indicating that the two are phylogenetically close. The genetic distinction of CMS $19 \mathrm{Y}^{\mathrm{T}}$ from $A$. agilis and from other species is even clearer in terms of absolute nucleotide changes along the 16S rDNA (data not shown). In Arthrobacter species, most of the nucleotide changes fall mainly into five broad hypervariable regions, i.e. between nucleotide positions 59 and 81 (23 bp), 173 and 192 (20 bp), 603 and 664 (62 bp), 1006 and 1052 (47 bp) and 1143 and 1163 (21 bp). It was interesting to note that CMS $19 \mathrm{Y}^{\mathrm{T}}$ confirms the general pattern of nucleotide variation seen among Arthrobacter species and differed by only $\sim 23$ nucleotides from $A$. agilis over the whole length of the four hypervariable regions ( $\sim 173 \mathrm{bp}$ in length). In addition, it did not have an $11 \mathrm{bp}$ sequence (CTGTCTTTTGG, between nucleotide positions 453 and 463) that is characteristic of $A$. agilis (data not shown).

Despite high 16S rRNA sequence homology (>97\%) and DNA similarity between micro-organisms ( $>70 \%$ ) phenotypic coherence among strains should be the deciding factor in the identification of species since it is still not established as to whether species should be delineated at the 60 or $80 \%$ DNA-DNA similarity level (Stackebrandt \& Goebel, 1994). In the present study, the genetic status of CMS $19 \mathrm{Y}^{\mathrm{T}}$ as a new Arthrobacter species is also supported by the phenotypic data, which established it as a member of the genus Arthrobacter but with a number of phenotypic characteristics different from those of $A$. agilis (Table 1) and other described species (Table 2). CMS $19 \mathrm{Y}^{\mathrm{T}}$ is also distinctly different from A. psychrolactophilus sp. nov., a psychrophilic Arthrobacter species (LovelandCurtze et al., 1999) that is more related to $A$. polychromogenes, $A$. oxydans and $A$. globiformis. Furthermore, in $A$. psychrolactophilus (unlike CMS $19 \mathrm{Y}^{\mathrm{T}}$ ) pigment production is dependent on media and growth conditions; the two species also differ with respect to their fatty acid composition and other phenotypic traits (Loveland-Curtze et al., 1999). LV7, another psychrophilic member of the genus Arthrobacter, is, like CMS $19 \mathrm{Y}^{\mathrm{T}}$, an isolate from a cyanobacterial mat sample but differs from CMS $19 \mathrm{Y}^{\mathrm{T}}$ in that it does not grow above $24{ }^{\circ} \mathrm{C}$, does not exhibit a rod-coccus cycle, tolerates only $3.5 \% \mathrm{NaCl}$ in the medium and produces a cream or yellow pigment depending on media and growth conditions (LovelandCurtze et al., 1999). Therefore, we conclude that CMS $19 \mathrm{Y}^{\mathrm{T}}$ defines a new Arthrobacter species; it has been named A. flavus (wherein 'flavus' means 'yellow').

\section{Description of Arthrobacter flavus sp. nov.}

Arthrobacter flavus (fla'vus. L. adj. flavus yellow, the colour of a pigment that the bacterium produces).

Cells are aerobic, Gram-positive, non-spore-forming, non-motile, non-fermentative and exhibit a rodcoccus growth cycle. Colonies on peptone-yeast extract medium are yellow, round, smooth, convex and $0.5-2 \mathrm{~mm}$ in diameter. The pigment is insoluble in water but soluble in methanol and exhibits fine structure in its absorption spectrum with absorption maxima at 410, 440 and $470 \mathrm{~nm}$. Pigment production is not dependent on growth conditions or media composition. No growth factors are required. Grows between 5 and $30^{\circ} \mathrm{C}$, at $\mathrm{pH}$ 6-9 and tolerates up to $11.5 \%(\mathrm{w} / \mathrm{v}) \mathrm{NaCl}$. Optimal growth is observed at $25^{\circ} \mathrm{C}$ and $\mathrm{pH}$ 7. Positive for catalase, lipase, gelatinase and $\beta$-galactosidase but negative for oxidase, urease, phosphatase, indole production, nitrate reduction and levan formation. Unable to utilize a number of carbon compounds, such as sucrose, rhamnose, cellulose, arabinose, mellibiose, cellobiose, galactose, sucrose, fructose, mannose, trehalose, xylose, mannitol, raffinose, glycerol, ribose, lactose, lactic acid, adonitol, maltose, glucose, glucosamine, sorbitol, melezitol, $\beta$ hydroxy butyric acid, dulcitol, dextrose, polyethylene glycol, glycine, lysine, Na-citrate, Na-acetate, Nasuccinate, cellulose, inulin, meso-inositol, glutamic acid, L-alanine, phenylalanine, methionine, glutamine, arginine, serine, potassium hydrogen phosphate, myristic acid, ammonium formate, creatine, methanol, tyrosine, sodium pyruvate, glycogen, erythritol, tryptophan, ethanol and sodium thioglycolate. Able to utilize sorbitol as the only source of carbon. Unable to oxidize or ferment glucose, galactose, sucrose, thio- 
glycolate or mannose but able to acidify sucrose and hydrolyse aesculin but not starch or cellulose. The cell wall peptidoglycan type is Lys-Thr-Ala3 (the A3 $\alpha$ variant) and the major menaquinone is $\mathrm{MK}-9\left(\mathrm{H}_{2}\right)$. The cell wall sugars are galactose, glucose and ribose. The cellular fatty acids are $\mathrm{C}_{14: 0}, \mathrm{C}_{15: 0}$, anteiso- $\mathrm{C}_{15: 0}$, $\mathrm{C}_{16: 0}$, iso- $\mathrm{C}_{16: 0}, \mathrm{C}_{16: 1}, \mathrm{C}_{17: 0}$, anteiso- $\mathrm{C}_{17: 0}$, iso- $\mathrm{C}_{18: 0}$, $\mathrm{C}_{18: 0}$ and $\mathrm{C}_{20: 0}$. The $\mathrm{G}+\mathrm{C}$ content of the DNA is $64 \pm 2 \mathrm{~mol} \%$. Closely related phylogenetically to group I Arthrobacter species and exhibits maximum similarity to A. agilis $(97 \cdot 31 \%)$, as determined by $16 \mathrm{~S}$ rDNA analysis. Sensitive to all antibiotics tested: carbenicillin $(50 \mu \mathrm{g})$, tobramycin $(15 \mu \mathrm{g})$, chlortetracycline $(30 \mu \mathrm{g})$, polymyxin B $(300 \mu \mathrm{g})$, oxytetracycline $(30 \mu \mathrm{g})$, rifampicin $(5 \mu \mathrm{g})$, nitrofurantoin $(300 \mu \mathrm{g})$, penicillin $(10 \mu \mathrm{g})$, bacitracin $(10 \mu \mathrm{g})$, nitrofurazone $(10 \mu \mathrm{g})$, gentamicin $(10 \mu \mathrm{g})$, lincomycin $(2 \mu \mathrm{g})$, furazolidone $(50 \mu \mathrm{g})$, colistin $(10 \mu \mathrm{g})$, furoxone $(100 \mu \mathrm{g})$, kanamycin $(30 \mu \mathrm{g})$, nystatin $(100 \mu \mathrm{g})$, co-trimoxazole $(25 \mu \mathrm{g})$, chloramphenicol $(30 \mu \mathrm{g})$, ampicillin $(10 \mu \mathrm{g})$, tetracycline $(30 \mu \mathrm{g})$, amoxycillin $(100 \mu \mathrm{g})$, trimethoprim $(5 \mu \mathrm{g})$ and erythromycin $(15 \mu \mathrm{g})$. Isolated from a cyanobacterial mat sample from McMurdo Dry Valley, Antarctica. The type strain is CMS 19Y $\left(=\operatorname{MTCC} 3476^{\mathrm{T}}\right)$.

\section{REFERENCES}

Blenden, D. C. \& Goldberg, M. S. (1965). Silver impregnation stain for Leptospira and flagella. J Bacteriol 89, 899-900.

Chauhan, S. \& Shivaji, S. (1994). Growth and pigmentation in Sphingobacterium antarcticus, a psychrotrophic bacterium from Antarctica. Polar Biol 14, 31-36.

Collins, M. D., Pirouz, T., Goodfellow, M. \& Minnikin, D. E. (1977). Distribution of menaquinones in actinomycetes and corynebacteria. J Gen Microbiol 100, 221-230.

Denhardt, D. T. (1966). A membrane filter technique for the detection of complementary DNA. Biochem Biophys Res Commun 23, 641-646.

Dumphy, P. J., Phillips, P. G. \& Brodie, A. F. (1971). Separation and identification of menaquinones from microorganisms. $J$ Lipid Res 12, 442-449.

Felsenstein, J. (1993). PHYLIP (Phylogeny Inference Package) version 3.5c. Department of Genetics, University of Washington, Seattle, USA.

Funke, G., Hutson, R. A., Bernard, K. A., Pfyffer, G. E., Wauters, G. \& Collins, M. D. (1996). Isolation of Arthrobacter spp. from clinical specimens and description of Arthrobacter cumminsii sp. nov. and Arthrobacter woluwensis sp. nov. J Clin Microbiol 34, 2356-2363.

Gounot, A. M. (1967). Role biologique des Arthrobacter dans les limons sonterrains. Ann Inst Pasteur Paris 113, 923-945.

Higgins, D. G., Bleasby, A. T. \& Fuchs, R. (1992). CLUSTAL V: improved software for multiple sequence alignment. $C A B I O S$ 8, 189-191.

Holding, A. J. \& Collee, J. G. (1971). Routine biochemical tests. Methods Microbiol 6A, 2-32.

Hou, X. G., Kawakura, Y., Sultana, F., Shu, S., Hirose, K., Goto, K. \& Ezaki, T. (1998). Description of Arthrobacter creatinolyticus sp. nov. isolated from human urine. Int $J$ Syst Bacteriol 48, 423-429.
Hugh, R. \& Leifson, E. (1953). The taxonomic significance of fermentative versus oxidative metabolism of carbohydrates by various gram-negative bacteria. J Bacteriol 66, 24-26.

Jagannadham, M. V., Rao, V. J. \& Shivaji, S. (1991). The major carotenoid pigment of a psychrotrophic Micrococcus roseus: purification, structure, and interaction of the pigment with synthetic membranes. J Bacteriol 173, 7911-7917.

Johnson, R. M. \& Bellinoff, R. D. (1981). A taxonomic study of a dominant coryneform bacterial type found in Antarctic soils. Antarct Res Ser 30, 169-184.

Johnson, R. M., Inai, M. \& McCarthy, S. (1981). Characteristics of cold desert Antarctic coryneform bacteria. J Ariz-Nev Acad Sci 16, 51-60.

Keddie, R. M. \& Jones, D. (1981). Aerobic saprophytic coryneform bacteria. In The Prokaryotes, vol. 2, pp. 1838-1878. Edited by M. P. Starr, H. Stolp, H. G. Trüper, A. Balows \& H. G. Schlegel. New York: Springer.

Keddie, R. M., Collins, M. D. \& Jones, D. (1986). Genus Arthrobacter Conn and Dimmick 1947. In Bergey's Manual of Systematic Bacteriology, vol. 2, pp. 1288-1301. Edited by P. H. A. Sneath, N. S. Mair, M. E. Sharpe \& J. G. Holt. Baltimore: Williams \& Wilkins.

Kimura, M. (1980). A simple method for estimating evolutionary rates of base substitutions through comparative studies of nucleotide sequences. $J$ Mol Evol 16, 111-120.

Koch, C., Schumann, P. \& Stackebrandt, E. (1995). Reclassification of Micrococcus agilis (Ali-Cohen 1889) to the genus Arthrobacter as Arthrobacter agilis comb. nov., and emendation of the genus Arthrobacter. Int J Syst Bacteriol 45, 837-839.

Komagata, K. \& Suzuki, K. I. (1987). Lipid and cell wall analysis in bacterial systematics. Methods Microbiol 19, 161-206.

Lane, D. J. (1991). 16S/23S rRNA sequencing. In Nucleic Acid Techniques in Bacterial Systematics, pp. 115-147. Edited by E. Stackebrandt \& M. Goodfellow. New York: Wiley.

Loveland-Curtze, J., Sheridan, P. P., Gutshall, K. R. \& Brenchley, J. E. (1999). Biochemical and phylogenetic analyses of psychrophilic isolates belonging to the Arthrobacter subgroup and description of Arthrobacter psychrolactophilus sp. nov. Arch Microbiol 171, 355-363.

Madden, J. M., Siegel, S. K. \& Johnson, R. M. (1979). Taxonomy of some Antarctic Bacillus and Corynebacterium species. Antarct Res Ser 30, 77-103.

Marmur, J. (1961). Procedure for the isolation of deoxyribonucleic acid from microorganisms. J Mol Biol 3, 208-218.

Matsumoto, G. I. (1993). Geochemical features of the McMurdo Dry Valley lakes, Antarctica. Physical and biogeochemical processes in Antarctic lakes. Antarct Res Ser 49, 95-118.

Matsumoto, G. I., Ohtani, S. \& Hiroto, K. (1993). Biogeochemical features of hydrocarbons in cyanobacterial mats from the McMurdo Dry Valley, Antarctica. Proc NIPR Symp Polar Biol 6, 98-105.

Minnikin, D. E., Alshamaony, L. \& Goodfellow, M. (1975). Differentiation of Mycobacterium, Nocardia and related taxa by thin-layer chromatographic analysis of whole-organism methanolysates. J Gen Microbiol 88, 200-204.

Moiroud, A. \& Gounot, A. M. (1969). Sur une bacterie psychrophile obligatoire isolee de limons glaciares. Hebd Seances Acad Sci Ser D Sci Nat 269, 2150-2152.

Osorio, C. R., Barja, J. L., Hutson, R. A. \& Collins, M. D. (1999). Arthrobacter rhombi sp. nov. isolated from Greenland halibut (Reinhardtius hippoglossoides). Int J Syst Bacteriol 49, 1217-1220. 
Rigby, P. W. J., Dieckmann, M., Rhodes , C. \& Berg, P. (1977). Labelling deoxyribonucleic acid to high specific activity in vitro by nick translation with DNA polymerase I. $J$ Mol Biol 113, 237-245.

Rosenthal, R. S. \& Dziarski, R. (1994). Isolation of peptidoglycan and soluble peptidoglycan fragment. Methods Enzymol 235, 253-285.

Schildkraut, C. \& Leifson, S. (1965). Dependence of the melting temperature of DNA on salt concentration. Biopolymers $\mathbf{3}$, 195-208.

Schleifer, K. H. (1986). Family I. Micrococcaceae, Prevot $31^{\mathrm{AL}}$. In Bergey's Manual of Systematic Bacteriology, vol. 2, pp. 1003-1008. Edited by P. H. A. Sneath, N. S. Mair, M. E. Sharpe \& J. G. Holt. Baltimore: Williams \& Wilkins.

Schleifer, K. H. \& Kandler, O. (1972). Peptidoglycan types of bacterial cell walls and their taxonomic implications. Bacteriol Rev 36, 407-477.

Shivaji, S., Rao, N. S., Saisree, L., Sheth, V., Reddy, G. S. N. \& Bhargava, P. M. (1988). Isolation and identification of Micrococcus roseus and Planococcus sp. from Schirmacher Oasis, Antarctica. J Biosci 113, 409-414.

Shivaji, S., Rao, N. S., Saisree, L., Reddy, G. S. N., Seshu Kumar, G. \& Bhargava, P. M. (1989a). Isolates of Arthrobacter from the soils of Schirmacher Oasis, Antarctica. Polar Biol 10, 225-229.

Shivaji, S., Rao, N. S., Saisree, L., Sheth, V., Reddy, G. S. N. \& Bhargava, P. M. (1989b). Isolation and identification of Pseudomonas sp. from Schirmacher Oasis, Antarctica. Appl Environ Microbiol 55, 767-770.

Shivaji, S., Ray, M. K., Seshu Kumar, G., Reddy, G. S. N., Saisree, L. \& Wynn-Williams, D. D. (1991). Identification of Janthinobacterium lividum from the soils of the islands of Scotia Ridge and from Antarctic peninsula. Polar Biol 11, 267-272.

Shivaji, S., Ray, M. K., Saisree, L., Jagannadham, M. V., Seshu Kumar, G., Reddy, G. S. N. \& Bhargava, P. M. (1992). Sphingobacterium antarcticus $\mathrm{sp}$. nov. a psychrotrophic bacterium from the soils of Schirmacher Oasis, Antarctica. Int J Syst Bacteriol 42, 102-116.

Siebert, J. \& Hirsch, P. (1988). Charcterization of 15 selected coccal bacteria isolated from Antarctic rock and soil samples from the McMurdo valley (South Victorialand). Polar Biol 9, $37-44$.

Stackebrandt, E. \& Goebel, B. M. (1994). Taxonomic note: a place for DNA-DNA reassociation and $16 \mathrm{~S}$ rRNA sequence analysis in the present species definition in bacteriology. Int $J$ Syst Bacteriol 44, 846-849.

Stackebrandt, E., Fowler, J. J., Fiedler, F. \& Seiler, H. (1983). Taxonomic studies on Arthrobacter nicotianae and related taxa: description of Arthrobacter uratoxydans sp. nov. and Arthrobacter sulfureus sp. nov. and reclassification of Brevibacterium protophormiae as Arthrobacter protophormiae comb. nov. Syst Appl Microbiol 4, 470-486.

Stackebrandt, E., Koch, C., Gvozdiak, O. \& Schumann, P. (1995). Taxonomic dissection of the genus Micrococcus: Kocuria gen. nov., Nesterenkonia gen. nov., Kytococcus gen. nov., Dermacocccus gen. nov., and Micrococcus Cohn 1872 gen. emend. Int J Syst Bacteriol 45, 682-692.

Stanier, R. Y., Palleroni, N. J. \& Doudoroff, M. (1966). The aerobic pseudomonads: a taxonomic study. J Gen Microbiol 43, 159-271.

Stead, D. F., Sellwood, J. G., Wilson, J. \& Viney, I. (1992). Evaluation of commercial microbial identification system based on fatty acid profiles and rapid, accurate identification of plant pathogenic bacteria. J Appl Bacteriol 72, 315-321.

Stolp, H. \& Gadkari, D. (1981). Nonpathogenic members of the genus Pseudomonas. In The Prokaryotes, vol. 1, pp. 719-741. Edited by M. P. Starr, H. Stolp, H. G. Trüper, A. Balows \& H. G. Schlegel. Berlin: Springer.

Suzuki, K. \& Komagata, K. (1983a). Taxonomic significance of cellular fatty acid composition in some coryneform bacteria. Int J Syst Bacteriol 33, 188-200.

Suzuki, K. \& Komagata, K. (1983b). Pimelobacter gen. nov., a new genus of corenyform bacteria with LL-diaminopimelic acid in the cell wall. J Gen Appl Microbiol 29, 59-71.

Suzuki, K., Collins, M. D., lijima, E. \& Komagata, K. (1989). Chemotaxonomic characterization of a radiotolerant bacterium, Arthrobacter radiotolerans: description of Rubrobacter radiotolerans gen. nov. comb. nov. FEMS Microbiol 52, 33-40.

Takeuchi, M. \& Hatano, K. (1998). Union of the genera Microbacterium Orla-Jensen and Aureobacterium Collins et al. in a redefined genus Microbacterium. Int J Syst Bacteriol 48, 739-747.

Tourova, T. P. \& Antonov, A. S. (1987). Identification of microorganisms by rapid DNA-DNA hybridisation. Methods Microbiol 19, 333-355.

Woese, C. R., Gutell, R., Gupta, R. \& Noller, H. F. (1983). Detailed analysis of the higher order structure of $16 \mathrm{~S}$-like ribosomal ribonucleic acids. Microbiol Rev 47, 621-669. 